\title{
Effect of milk fat globule membrane materials on the crystallization behaviour in dairy recombined cream
}

\author{
${ }^{1, * \text { Phan, T.T.Q., }}{ }^{2}$ Le, T.T. and ${ }^{3}$ Dewettinck, K. \\ ${ }^{1}$ Department of Food Technology, College of Agriculture, Can Tho University, 3/2 street, Ninh Kieu \\ District, Can Tho City, Viet Nam \\ ${ }^{2}$ Faculty of Food Science and Technology, Nong Lam University, Thu Duc District, Ho Chi Minh City, \\ Vietnam \\ ${ }^{3}$ Laboratory of Food Technology and Engineering, Department of Food Safety and Food Quality, Ghent \\ University, Coupure Links 653, B-9000 Ghent, Belgium
}

\begin{abstract}
Article history:
Received: 2 March 2020

Received in revised form: 4 April 2020

Accepted: 8 April 2020

Available Online: 26 April 2020
\end{abstract}

\section{Keywords:}

Buttermilk,

Crystallization,

Partial coalescence,

Polar lipids

\section{DOI:}

https://doi.org/10.26656/fr.2017.4(5).092

\begin{abstract}
Milk fat globule membrane (MFGM) fragments were isolated from reconstituted buttermilk (BM-MFGM) and from buttermilk whey (whey-MFGM) and used to make recombined cream. Besides, the commercial dairy ingredient, Lacprodan ${ }^{\circledR}$ PL20, a material rich in milk polar lipids and proteins, was used as another MFGM source. Recombined cream was prepared by homogenizing $35 \%(\mathrm{w} / \mathrm{w})$ anhydrous milk fat into an aqueous phase containing individual BM-MFGM, Whey-MFGM, Lacprodan ${ }^{\circledR}$ PL20, or buttermilk powder (BMP) or a mixture of MFGM materials and BMP $(4: 6, \mathrm{w} / \mathrm{w})$. The effect of MFGM on the fat crystallization behaviour, shear-induced partial coalescence was investigated and compared to those of natural cream and recombined cream made with BMP. It was found that the physicochemical properties of recombined cream were strongly affected by the MFGM source. Shear-induced partial coalescence of WheyMFGM40 was slower compared to that of natural cream. Amongst the four emulsifier materials used in this study, Whey-MFGM showed a similar crystallization behaviour to natural cream.
\end{abstract}

\section{Introduction}

Cream or natural cream is a dairy product rich in fat, obtained by separation of the fat phase from raw milk. This oil-in-water emulsion is used as an ingredient in many food products and sometimes consumed directly (van Lent et al., 2008). Natural cream is obtained directly from the fresh cow's milk (Fredrick, 2011).

Recombined cream (RC) can be used as an alternative for natural cream. It is produced by recombining milk ingredients. The advantages of recombined cream over natural cream are the cost reduction for storage of the raw materials, the easy modification and standardization of the composition and desired properties and a composition that is independent of the milking season (van Lent et al., 2008). It can be used, as an alternative for natural cream, in the production of many dairy products such as whipped cream, cheese, ice-cream, etc. (Vanderghem et al., 2007). To produce whipped cream with a good texture, controlled partial coalescence of the recombined cream is needed (Dickinson, 2010). However, recombined cream has divergent physicochemical and sensory properties compared to natural cream. The rate of partial coalescence of fat globules in natural cream and recombined cream vary to a large extent from each other. The main reason could be the difference in the composition of the interfacial layer and the fat crystallization behaviour of natural cream and recombined cream (Fredrick, 2011). In recombined cream, the fat globules are not surrounded by the original MFGM membrane. The adsorption conditions, such as the composition of the aqueous phase, the fat: protein ratio, temperature and agitation, strongly influences the nature of the newly formed MFGM. Caseins and whey proteins are present in the membrane of the reconstituted cream (Ward et al., 2006). The main disadvantages of recombined whipped creams are lower stability and overrun. The physicochemical properties can be enhanced and the partial coalescence can be promoted by the addition of small molecular weight surfactants (Goff, 1997). 
Fat globules in milk are surrounded by a milk fat globule membrane (MFGM). The MFGM consists mainly of membrane proteins and polar lipids. It has been reported that MFGM components have good emulsifying properties (Kanno, 1989). Milk phospholipids, a class of polar lipids were found to have good emulsifying properties. They are mainly present in the MFGM together with proteins and other polar lipids. There has been a great interest in these molecules (phospholipids) because they act as an emulsifier and as a stabilizer. The MFGM is rich in phospholipids. They have been considered as a natural surface active material, because they are very effective in reducing the interfacial tension (Contarini and Povolo, 2013). Some by-products of the dairy industry, such as buttermilk and buttermilk whey are enriched in MFGM (Rombaut et al., 2007). Lacprodan ${ }^{\circledR}$ PL-20, a dairy formulation enriched with milk polar lipids and proteins is also found to have good emulsifying properties.

The main objective of this work is to study the effect of MFGM on the fat crystallization behaviour, the solid fat content and the shear-induced partial coalescence of RC. Partial coalescence rate plays a key role in obtaining the desired structure. Rotational viscosimetry was used to study the shear-induced partial coalescence of the above mentioned recombined creams. To gain more insight in the mechanism of partial coalescence, the solid fat content, particle size distribution and isothermal fat crystallization behaviour of RCs were investigated and compared to natural cream, derived directly from fresh cow's milk and recombined cream prepared with buttermilk powder (BMP).

\section{Materials and methods}

\subsection{Materials}

Buttermilk powder and anhydrous milk fat were obtained from FrieslandCampina (Lummen, Belgium). Whey buttermilk was delivered by a local dairy company (Büllinger Butterei, Büllinger, Belgium). In addition, Lacprodan ${ }^{\circledR}$ PL-20 in the form of spray-dried powder (rich in milk phospholipids and proteins) was also obtained from Arla Foods (Denmark).

\subsection{Isolation of MGFM materials}

Reconstituted buttermilk was prepared according to Le et al. (2011). Trisodium citrate $(1 \% \mathrm{w} / \mathrm{w})$ was added to dissociate casein micelles into casein components which were small enough to permeate the membrane during the filtration process (Corredig et al., 2003). For whey buttermilk, the $\mathrm{pH}$ was adjusted to 7.5 by adding $1 \mathrm{~N} \mathrm{KOH}$ before microfiltration (Rombaut et al., 2007). Cross-flow microfiltration was performed in combination with continuous diafiltration (rate of water addition was equal to the permeate rate) to separate the MFGM fragments from the two materials (reconstituted buttermilk and buttermilk whey) (Phan et al., 2013). The membrane module was designed with a Millipore frame with a Pellicon ${ }^{\circledR} 2$ microfiltration cassette filter (PVGVPPC05), a Durapore membrane ${ }^{\circledR}$ consisting of hydrophilic polyvinylidene fluoride (PVDF) with a pore size of $0.22 \mu \mathrm{m}$ and a screen (type $C$ ) with a surface area of $0.5 \mathrm{~m}^{2}$. The obtained materials from the buttermilk and whey buttermilk after microfiltration were called BM-MFGM and whey-MFGM, respectively. WheyMFGM and BM-MFGM were stored at a temperature below $-20^{\circ} \mathrm{C}$.

\subsection{Experimental design}

In order to make $\mathrm{RC}$, the RC's were prepared using various MFGM materials such as BM-MFGM, wheyMFGM and Lacprodan ${ }^{\circledR}$ PL-20. The MFGM materials were also mixed together with BMP in different ratios. The protein content of RC's was standardized $(2.3 \mathrm{~g} / 100 \mathrm{~g})$. The experimental design and the composition of materials used in $\mathrm{RC}$ are given in Table 1.

The dairy materials were dissolved in deionized water using a magnetic stirrer. The $\mathrm{pH}$ of the solution was adjusted to 7 using sodium hydroxide $0.1 \mathrm{~N}$. The reconstituted solution was stored at $4{ }^{\circ} \mathrm{C}$ for complete hydration. Afterwards, $35 \%$ of anhydrous milk fat was added to the reconstituted solution (35\% AMF) before pre-heating to $65^{\circ} \mathrm{C}$. The emulsion was pre-homogenized using an ULTRA-Turrax (IKA ${ }^{\circledR}$ - Werke, Germany) at $13000 \mathrm{rpm}$ for $6 \mathrm{mins}$. The homogenization was performed in a two-step lab-scale high pressure homogenizer (APV cooling systems, Alberslund, Denmark). A pressure of 20 bars was maintained throughout the homogenization. After homogenization, the obtained cream was cooled rapidly to $5^{\circ} \mathrm{C}$ and stored at $5^{\circ} \mathrm{C}$ for further analysis. The physicochemical characteristics of the $\mathrm{RC}$ were determined and compared with the natural cream. All the experiments were done in triplicate.

\subsection{Determination of physicochemical properties of cream}

\subsubsection{Isothermal crystallization behaviour of cream}

Differential scanning calorimetry (DSC; TA Q1000 DSC (TA Instruments, New Castle, Delaware, USA) was used to study the isothermal crystallization behaviour of cream at $5^{\circ} \mathrm{C}$ as described by Fredrick (2011). Cream samples $(5-15 \mathrm{mg})$ were weighed on an analytical balance (Sartorius, CP225D, Germany). The timetemperature program (t-T) was applied as follows: (i) holding the sample at $65^{\circ} \mathrm{C}$ for 10 mins, (ii) cooling at 
Table 1. The experimental design and composition of recombined creams

\begin{tabular}{|c|c|c|c|c|c|}
\hline \multirow{2}{*}{ Type of cream } & \multicolumn{2}{|c|}{ MFGM materials /BMP ratio } & \multirow{2}{*}{$\begin{array}{c}\text { MFGM materials } \\
\text { (\% dry matter) }\end{array}$} & \multirow{2}{*}{$\begin{array}{c}\text { BMP } \\
\text { (\% dry matter) }\end{array}$} & \multirow{2}{*}{$\begin{array}{c}\text { Water } \\
(\%)\end{array}$} \\
\hline & MFGM materials & BMP & & & \\
\hline Whey-MFGM40 & 4 & 6 & 3.44 & 3.82 & 54.74 \\
\hline BM-MFGM40 & 4 & 6 & 1.32 & 3.82 & 59.86 \\
\hline Lacprodan40 & 4 & 6 & 1.76 & 3.82 & 59.42 \\
\hline Whey-MFGM100 & 10 & 0 & 8.52 & 0 & 56.48 \\
\hline BM-MFGM100 & 10 & 0 & 3.3 & 0 & 61.7 \\
\hline Lacprodan100 & 10 & 0 & 4.41 & 0 & 60.59 \\
\hline BMP100 & 0 & 10 & 0 & 6.37 & 58.63 \\
\hline
\end{tabular}

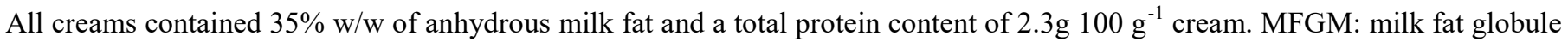
membrane; BMP: buttermilk powder, whey-MFGM40: cream with mixture of microfiltered buttermilk whey and BMP (4/6 w/ w); BM-MFGM40: cream with mixture of microfiltered buttermilk and BMP (4/6 w/w); Lacprodan40: cream with mixture of Lacprodan ${ }^{\circledR}$ PL20 and BMP (4/6 w/w); whey-MFGM100: cream with individual microfiltered buttermilk whey; BMMFGM100: cream with individual microfiltered buttermilk; Lacprodan100: cream with individual Lacprodan ${ }^{\circledR}$ PL20; BMP100: cream with individual buttermilk powder.

$25^{\circ} \mathrm{C} \min ^{-1}$ to $5^{\circ} \mathrm{C}$ and (iii) holding at $5^{\circ} \mathrm{C}$ for $x \min (x$ may vary from 0 to 120 mins) and (iv) heating at $20^{\circ} \mathrm{C}$ $\min ^{-1}$ until $65^{\circ} \mathrm{C}$. The $\mathrm{t}-\mathrm{T}$ program was repeated for several defined isothermal periods. The recorded melting curves were integrated using a horizontal linear baseline with a fixed endpoint at $55^{\circ} \mathrm{C}$. The melting heat $\left(\mathrm{J} \mathrm{g}^{-1}\right)$ was plotted as a function of the holding time at $5^{\circ} \mathrm{C}$.

\subsubsection{Solid fat content (SFC)}

SFC was measured with Maran Ultra $23 \mathrm{MHz}$ pulsed -field-gradient nuclear magnetic resonance (NMR) (Oxford Instruments, Abingdon, UK). In this NMR, the indirect SFC-method was chosen. The SFC was calculated after determining the FID-signals (free induction decay) at $70 \mu$ s of cream $\left(\mathrm{L}_{\mathrm{cr}}\right)$ and rapeseed oil $\left(\mathrm{L}_{\text {oil }}\right)$ per gram, both at crystallization or holding temperature $\left(\mathrm{T}_{5^{\circ}} \mathrm{C}\right)$ and at a temperature above the final melting point of the cream (i.e.. $45^{\circ} \mathrm{C} ; \mathrm{T}_{45^{\circ} \mathrm{C}}$. All calculations of the SFC content of cream were according to Fredrick (2011).

In order to perform the NMR measurements, around $0.5 \mathrm{~g}$ of the sample was filled in the NMR-tubes. The mass was determined on the analytical balance (Saratorius CP225D, Germany). The samples were placed in a water bath at $45^{\circ} \mathrm{C}$ and after 10 mins their FID-signal was recorded at $45^{\circ} \mathrm{C}$. Throughout the experiment, the samples were stored at $5^{\circ} \mathrm{C}$. The temperature in the probe was controlled by an external water bath. The NMR tubes were transferred to the water bath at $5^{\circ} \mathrm{C}$ and the FID-signal was recorded after holding the samples for 2 hours, 1 day, 3 days and 5 days of storage at $5^{\circ} \mathrm{C}$. The FID-signal was measured at $5^{\circ} \mathrm{C}$. All measurements were performed in duplicate.

\subsubsection{Shear-induced partial coalescence}

Shear-induced partial coalescence measurements were performed after 7 days of storage using rotational viscosity analysis. An AR2000 controlled stress rheometer (TA instruments, Brussels, Belgium) equipped with a starch pasting cell geometry composed of the jacket, removable cup and an impeller (diameter $32 \mathrm{~mm}$, height $122 \mathrm{~mm}$ ), was used. Each time, $30 \mathrm{~g}$ of sample was weighed into the cup and, after an equilibration period at the measuring temperature $\left(20^{\circ} \mathrm{C}\right)$, a constant shear rate of $150 \mathrm{~s}^{-1}$ was applied to induce partial coalescence (Fredrick, 2011). The change in apparent viscosity of the cream as a function of time was recorded until a maximum was reached, indicating the occurrence of phase inversion. All measurements were performed in duplicate the results were plotted.

\subsubsection{Particle size distribution}

The particle size distribution of the creams was measured using a long bench Malvern Mastersizer S (Malvern Instruments, Malvern, UK) with a MS17automated sample dispersion unit. The presentation code $1.492,0.01,1.330$ corresponding respectively to the particle refractive index, particle absorption, and dispersant refractive index, was used. Prior to the measurements, $1 \%$ of the cream was heated $\left(50^{\circ} \mathrm{C}\right)$ to avoid scattering of fat crystals present in the milk fat globules and then dissolved in 1\% SDS solution. For each composition, three creams were prepared independently and measured at least in duplicate.

\subsection{Statistical analysis}

Statistical analysis was performed using S-Plus ${ }^{\circledR} 8.0$ package for Windows (Tibco Software Inc., Palo Alto, CA, USA). One-way analysis of variance (ANOVA) and Tukey's test was used for multiple comparisons of means. The differences were considered statistically significant at $\mathrm{P} \leq 0.05$. 
Table 2. Composition of emulsifying materials expressed as \% on dry-matter basis.

\begin{tabular}{lccccc}
\hline \multicolumn{1}{c}{ Materials } & Total protein & Casein/whey protein ratio & Total lipids & Ash & Polar lipids \\
\hline BMP & $34.25 \pm 0.14^{\mathrm{b}}$ & $1.75 \pm 0.01^{\mathrm{d}}$ & $8.37 \pm 0.30^{\mathrm{a}}$ & $7.13 \pm 0.05^{\mathrm{c}}$ & $3.27 \pm 0.13^{\mathrm{a}}$ \\
BM-MFGM & $69.63 \pm 1.30^{\mathrm{d}}$ & $1.02 \pm 0.02^{\mathrm{b}}$ & $23.80 \pm 0.61^{\mathrm{b}}$ & $3.25 \pm 0.17^{\mathrm{a}}$ & $9.30 \pm 0.31^{\mathrm{b}}$ \\
Whey-MFGM & $26.50 \pm 1.19^{\mathrm{a}}$ & $0.14 \pm 0.01^{\mathrm{a}}$ & $39.01 \pm 0.20^{\mathrm{d}}$ & $23.39 \pm 0.31^{\mathrm{d}}$ & $12.10 \pm 0.19^{\mathrm{c}}$ \\
Lacprodan ${ }^{\mathrm{a} P L 20}$ & $52.22 \pm 1.27^{\mathrm{c}}$ & $1.26 \pm 0.08^{\mathrm{c}}$ & $31.10 \pm 0.57^{\mathrm{c}}$ & $6.46 \pm 0.10^{\mathrm{b}}$ & $23.10 \pm 0.70^{\mathrm{d}}$ \\
\hline
\end{tabular}

Data are represented as mean \pm SD of three replicates; different superscript letters within a column refer to statistically significant differences (Tukey's test, $\mathrm{P} \leq 0.05$ ).

${ }^{1}$ The casein/whey protein ratio is a relative estimation using densitometry (Phan et al., 2013).

BMP: Buttermilk powder; BM-MFGM: Microfiltered buttermilk; whey-MFGM: microfiltered buttermilk milk; Lacprodan ${ }^{\circledR}$ PL20: Lacprodan

\section{Results}

\subsection{Composition of the experimental materials}

The composition of the experimental materials was significantly different from each other (Table 2). These results have been reported and discussed in Phan et al. (2013).

\subsection{Isothermal crystallization behaviour of cream}

For all samples, melting heat was already detected from the moment the temperature reached $5^{\circ} \mathrm{C}(\mathrm{t}=0$ min) indicating that milk fat in the cream already started to crystallize during the preceded cooling. Table 3 shows the crystallization temperatures $\left(\mathrm{T}_{\mathrm{cr}}\right)$ of the $\mathrm{NC}$ and the RCs prepared with different MFGM materials and a mixture of MFGM material and BMP. The $\mathrm{T}_{\mathrm{cr}}$ of $\mathrm{NC}$ was significantly different from that of RCs, except for Lacprodan100. The $\mathrm{T}_{\mathrm{cr}}$ of $\mathrm{RC}$ BMP100, i.e. $18.17 \pm 0.44^{\circ} \mathrm{C}$, was higher than the value of $11.1 \pm 0.6^{\circ} \mathrm{C}$ reported by Fredrick (2011), while the $\mathrm{T}_{\mathrm{cr}}$ of $\mathrm{NC}$ obtained in this study is in line with the result of these authors $\left(14.4 \pm 0.2^{\circ} \mathrm{C}\right)$. This can probably be explained by the difference in $\mathrm{t}-\mathrm{T}$ history during processing (e.g. the production of cream on the lab-scale conditions and of a typical industrial $\mathrm{RC}$ ), of the starting materials and the storage conditions.

The crystallization profiles of $\mathrm{NC}$ versus $\mathrm{RCs}$ prepared with individual MFGM material and with a mixture of MFGM material and BMP (4:6, w/w), respectively (Figure 1-A and $\mathrm{B}$ ).

Figure 1-A and B show the isothermal crystallization curves of $\mathrm{NC}$ and RCs prepared with different MFGM materials at $5^{\circ} \mathrm{C}$ after fast cooling $\left(25^{\circ} \mathrm{C} \mathrm{min}^{-1}\right)$. The crystallization profiles all show a two-step crystallization. In the first step, $\alpha$-crystals are formed during the cooling and the beginning of the isothermal period. Secondly, $\beta$ '-crystals are shaped at the expense of $\alpha$-crystals (second step) while still, some $\alpha$-crystals remain present. However, the latter has a different composition than the initially created $\alpha$-crystals during cooling. In RCs of BM-MFGM40, BM-MFGM100 and BMP100, some differences in the crystallization kinetics can clearly be detected compared to that of $\mathrm{NC}$ and other RCs. In fact, interfacial heterogeneous nucleation took place during cooling. The slope of the second step of RC of BM-MFGM40, BM-MFGM100 and BMP100 is also steeper, hence the $\alpha-\beta$ ' polymorphic transition seems to be faster than that of the $\mathrm{NC}$ and other RCs. As a consequence, the crystallization of these RCs started at a higher temperature and the crystal growth and the $\alpha-\beta$ ' polymorphic transition was accelerated.

Table 3. Crystallization temperature $\left(\mathrm{T}_{\mathrm{cr}}\right)$ of different type of creams

\begin{tabular}{lc}
\hline Type of cream & $\mathrm{T}_{\mathrm{cr}}\left({ }^{\circ} \mathrm{C}\right)$ \\
\hline Whey-MFGM40 & $17.72 \pm 0.61^{\mathrm{cd}}$ \\
BM-MFGM40 & $17.34 \pm 0.28^{\mathrm{bcd}}$ \\
Lacprodan40 & $16.54 \pm 0.15^{\mathrm{bc}}$ \\
Whey-MFGM100 & $17.42 \pm 0.48^{\mathrm{bcd}}$ \\
BM-MFGM100 & $18.07 \pm 0.63^{\mathrm{d}}$ \\
Lacprodan100 & $16.38 \pm 0.33^{\mathrm{ab}}$ \\
BMP100 & $18.17 \pm 0.44^{\mathrm{d}}$ \\
NC & $15.21 \pm 0.45^{\mathrm{a}}$ \\
\hline
\end{tabular}

Data are expressed as mean values \pm SD of three replicates; superscript letters refer to statistically significant differences (Tukey's test, $\mathrm{P} \leq 0.05$ ).

MFGM: milk fat globule membrane; BMP: buttermilk powder, whey-MFGM40: cream with mixture of microfiltered buttermilk whey and BMP (4/6 w/w); BMMFGM40: cream with mixture of microfiltered buttermilk and BMP (4/6 w/w); Lacprodan40: cream with mixture of Lacprodan ${ }^{\circledR}$ PL20 and BMP (4/6 w/w); whey-MFGM100: cream with individual microfiltered buttermilk whey; BMMFGM100: cream with individual microfiltered buttermilk; Lacprodan100: cream with individual Lacprodan®PL20; BMP100: cream with individual buttermilk powder; NC: natural cream

Wiking et al. (2009) and Vanhoutte et al. (2002) reported that adding soybean PLs to a mixture of milk fat and water, retarded nucleation and crystal growth of the milk fat. Miura et al. (2006) investigated the effect of bovine- and soybean PLs on the milk fat crystallization and concluded that soybean PLs decreased the crystallization temperature during cooling and consequently lowered the solid fat content compared to 

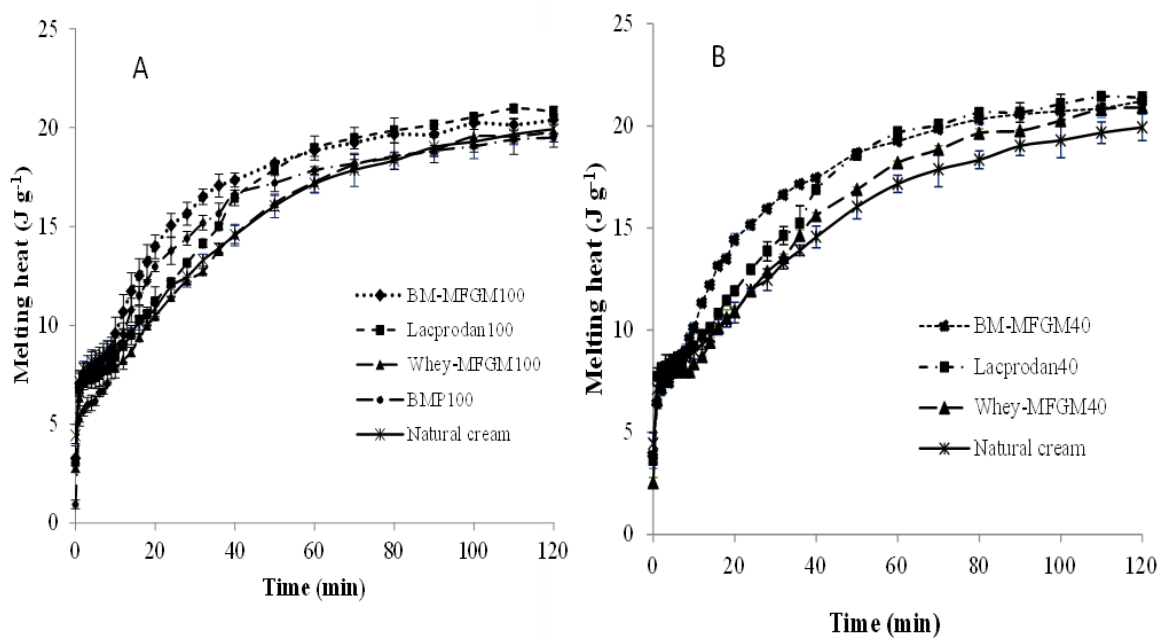

Figure 1. Isothermal crystallization curves at $5^{\circ} \mathrm{C}$ of $\mathrm{NC}$ and $\mathrm{RC}$ prepared with individual MFGM material (A) and with a mixture of MFGM material and BMP (4:6, w/w) (B) constructed by plotting the melting heat per $\mathrm{g}$ cream sample as function of the holding time

RCs containing bovine PLs. The PLs content in the aqueous phase of RC of BM-MFGM100, BM-MFGM40 and BMP100 were significantly lower than that in the aqueous phase of the RCs of Whey-MFGM40, WheyMFGM100, Lacprodan40 and Lacprodan100 (Table 1). Besides, the melting heat required to melt the crystals, created during each isothermal period of the RCs was higher than that of NC. The difference in nucleation mechanism and crystallization kinetics may result in a different number, size, arrangement and morphology of the crystals in the fat globule. However, microscopic analysis, to visualize fat crystals in the emulsion droplets, still needs to be performed.

\subsection{Solid fat content (SFC)}

To induce partial coalescence, a continuous fat crystal network is needed (Boode et al., 1993). This means that the SFC has a strong influence on the rate of partial coalescence. Figure 2 shows the SFC of NC and of RC, prepared with individual MFGM material or with a mixture of MFGM material and BMP (4:6, w/w), after 2 hours, 1 day, 3 days and 5 days storage at $5^{\circ} \mathrm{C}$.

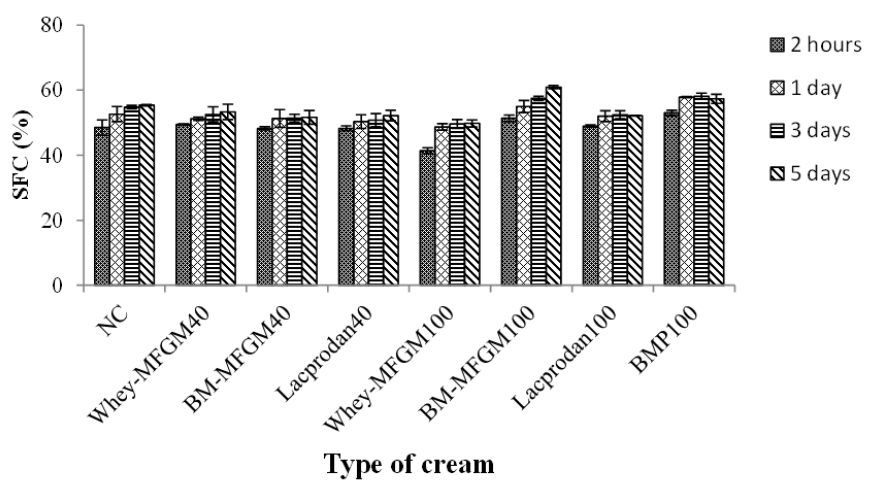

Figure 2. Solid fat content (SFC) of NC and RC prepared with individual MFGM material and with a mixture of MFGM material and BMP (4:6, w/w) after storage for 2 hrs, 1 day, 3 days and 5 days at $5^{\circ} \mathrm{C}$.
From the DSC-data shown in Figure 1, after 120 min, it seems that equilibrium in milk fat crystallization was reached in all RCs and NC. However, SFC measurements show some extra crystallization during the first day. The polymorphic transition probably continues after $120 \mathrm{~min}$ of crystallization at $5^{\circ} \mathrm{C}$ most likely combined with some additional crystallization of the triacylglycerols (TAGs) which did not crystallize immediately. The equilibrium SFC of RCs and NC is reached after 3 days of storage, except for the RC of BM -MFGM100. Among all types of cream, RC of WheyMFGM100 showed the lowest amount of SFC during 5 days of storage. The SFC of RC of Whey-MFGM40, BM -MFGM40, Lacprodan40 and Lacprodan100 was similar to that of NC, whereas the SFC of BM-MFGM100 and BMP100 was higher than that of NC.

\subsection{Shear-induced partial coalescence}

After storage of the recombined cream at $5^{\circ} \mathrm{C}$ for 7 days, the shear-induced partial coalescence was measured as a function of time by applying a constant shear rate of $150 \mathrm{~s}^{-1}$ at $20^{\circ} \mathrm{C}$. Figure 3 (A and B) shows that the churning time $\left(t_{\mathrm{ch}}\right)$ and the viscosity profile of $\mathrm{NC}$ and RC's were significantly different from each other.

The longest $t_{c h}$ was observed for the RC wheyMFGM100 $\left(\mathrm{t}_{\mathrm{ch}}=67\right.$ mins $)$ followed by $\mathrm{RC}$ Lacprodan $100\left(\mathrm{t}_{\mathrm{ch}}=27.8\right.$ mins $)$ and RC BM-MFGM100 $\left(\mathrm{t}_{\mathrm{ch}}=21\right.$ mins), while $\mathrm{t}_{\mathrm{ch}}$ of $\mathrm{NC}$ was 24.6 mins (Figure 3A). The difference in the shear-induced partial coalescence rate of $\mathrm{NC}$ and all RCs could be due to the different composition of the aqueous phases and the nature of the newly formed fat droplet membrane. The high concentration of polar lipids in the aqueous phase of whey-MFGM100 (Table 2) may provide stability to this RC. 

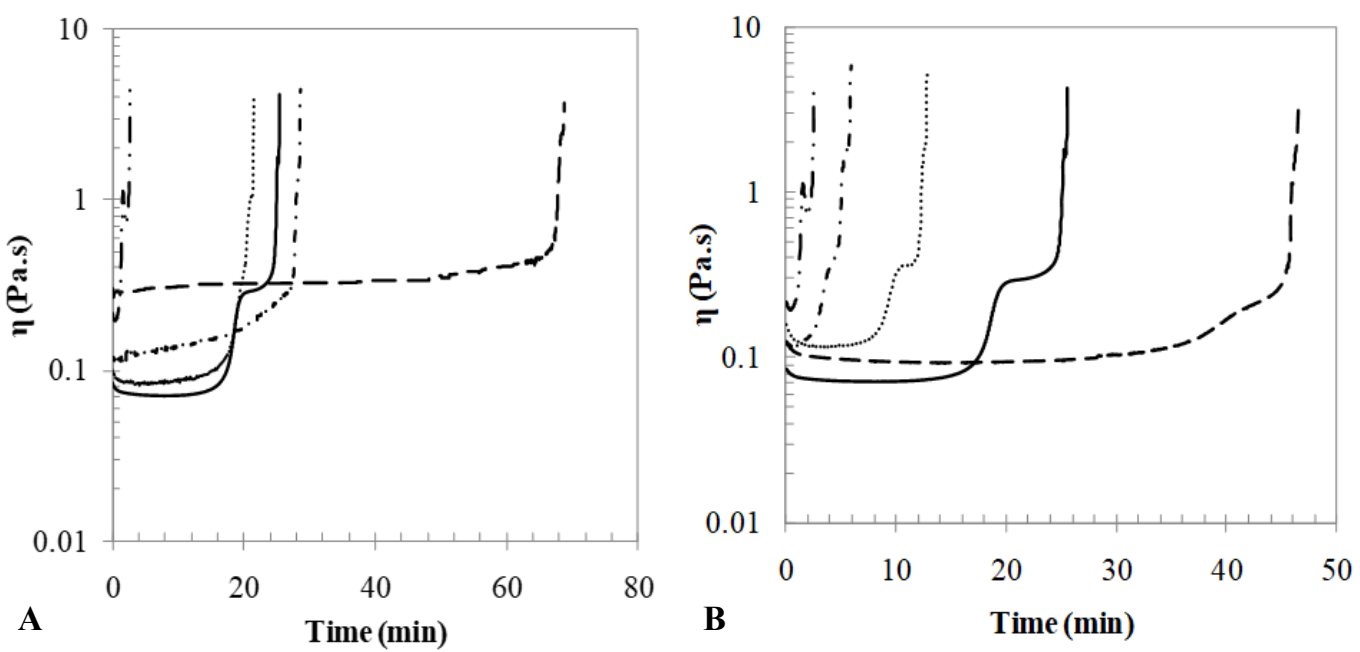

Figure 3. Viscosity profiles as function of time during continuous shearing at a shear rate of $150 \mathrm{~s}^{-1}$ at $20^{\circ} \mathrm{C}$ of $\mathrm{NC}$ and $\mathrm{RC}$ prepared with individual MFGM material (A) and with a mixture of MFGM material and BMP (4:6, w/w) (B). NC (一); RC Lacprodan40 and Lacprodan100 (----); RC BM-MFGM40 and BM-MFGM100 (......); RC whey-MFGM40 and wheyMFGM100 (-- -); RC BMP100 (- *- - *)

Compared to $\mathrm{NC}$ and RCs prepared with different MFGM materials and mixtures of MFGM material and $\mathrm{BMP}$, it was seen that an increase in the concentrations of BMP in RC increased the partial coalescence rates (Figure 3). The churning time of RC BMP100 was the shortest $\left(\mathrm{t}_{\mathrm{ch}}=2.3\right.$ mins $)$, provided the globule size distribution was similar (Figure 4). Goff (1997) reported that emulsions stabilized by whey proteins were more susceptible to partial coalescence than when they were stabilized with caseins. In the present study, the amount of caseins was high in BMP. However, casein micelles were present when BMP was dissolved in water. Those micelles were quite large and could stabilize neighboring fat droplets by positioning themselves at the interface of the fat globules (forming globule clusters). Consequently, the clusters of globules being larger compared to separated globules could collide more easily during churning. Vanapalli et al. (2002) reported that the long-lasting contact between globules in the clusters favoured the occurrence of partial coalescence.

For the sake of completeness, it should be mentioned that not only differences in interfacial composition, but also differences in crystallization behaviour between creams could (at least partly) explain changes in partial coalescence rate (data not shown).

\subsection{Particle size distribution}

Figure 4 shows the particle size distribution of natural cream and RC's prepared with 100\% BMP, and the mixture of $40 \%$ MFGM material and $60 \%$ BMP.

The particle size distribution for all RC's was comparable. NC had a narrower particle size distribution compared to that of RC's. It could be explained by the difference in composition of the membrane that surrounded the fat globule. In NC, the droplet size is a consequence of a natural process, while the droplet size of recombined cream depends on the energy-input during processing as well as on the availability of surface active materials (Ward et al., 2006). The particle size distributions of the recombined creams with $100 \%$ of MFGM materials were similar to the recombined creams with a mixture of $40 \%$ MFGM material and $60 \%$ BMP (data not shown).

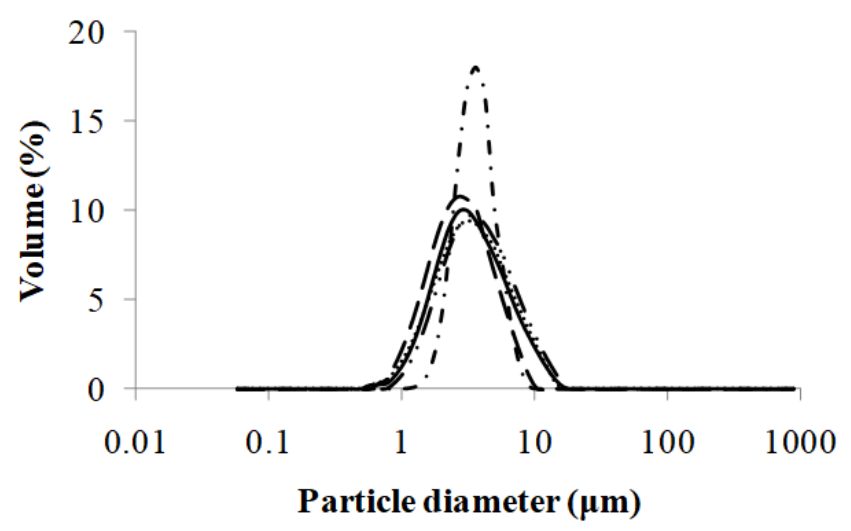

Figure 4. The particle size distribution of natural cream, NC $(-\cdot-\cdot) ; \quad$ recombined cream $(\mathrm{RC})$ prepared with $100 \%$ buttermilk powder, BMP100 $(-\cdot \cdot-\cdot \cdot)$; a mixture of $40 \%$ microfiltered buttermilk and $60 \%$ buttermilk powder, BMMFGM40 (......); a mixture of $40 \%$ microfiltered buttermilk whey and $60 \%$ buttermilk powder, whey-MFGM40 (- - ); a mixture of $40 \%$ Lacprodan ${ }^{\circledR}$ PL20 and $60 \%$ buttermilk powder, Lacprodan40 (-

\section{Discussion}

To obtain the desired product properties in whipped cream, partial coalescence is necessary. It influences the macroscopic product properties like overrun, firmness and stability. The increase in crystal size at rest and in Couette flow affects the emulsion stability. Consequently, the emulsion will be more susceptible to 
partial coalescence. The rate and extent of partial coalescence initially depend on the t-T history during processing. It is mainly influenced by the crystallization of milk fat and its kinetics. The differences in the concentration and composition of components (e.g. PLs, lactose and minerals) in the aqueous phase of RCs and $\mathrm{NC}$ may influence the fat crystallization behaviour (nucleation, crystal growth rate and polymorphic evolutions) and, therefore, the shear-induced partial coalescence and the whipping behaviour of creams.

Our data demonstrated that the rate and extent of partial coalescence initially depend on the t-T history during processing. It is mainly influenced by the crystallization of milk fat and its kinetics. The differences in the concentration and composition of components (e.g. PLs, lactose and minerals) in the aqueous phase of RCs and NC may influence the fat crystallization behaviour (nucleation, crystal growth rate and polymorphic evolutions) and, therefore, the shearinduced partial coalescence of creams. Among the RCs and $\mathrm{NC}$, the rate of partial coalescence of the FGs in NC and $\mathrm{RC}$ was found to be very different (Figure $3 \mathrm{~A}$ and 3B). The difference in the $t_{c h}$ of $\mathrm{NC}$ and all RCs can be due to the difference in the fat crystallization behaviour, the composition of the aqueous phases and the nature of the newly formed fat globule membrane (Figure 1, Table 2). Scott et al. (2003) reported that buttermilk or the aqueous phase derived from churning cream for making butter does increase the fluidity of the emulsion due to the presence of a high amount of phospholipids and unsaturated fatty acids. It has been found that RC made with buttermilk containing high amounts of phospholipids was more stable, more acid tolerant and had a higher droplet surface area than when the cream was made with buttermilk containing a lower amount of phospholipids (Ihara et al., 2011). However, Melsen (1987) showed that the shear-induced partial coalescence stability was similar for both RCs obtained by emulsifying milk fat in skimmed milk or in buttermilk, although the buttermilk had a much higher polar lipid content than the skimmed milk. It can be seen that the effect of polar lipids is dependent on the composition of the PLs (Table 2). In addition, MFGM materials used in this study were isolated from by-products of dairy industrial processing. Denatured whey proteins can affect the stability of the recombined creams. Britten et al. (1994) indicated that the resistance to the shearinduced partial coalescence was improved by increasing the proportion of denatured whey protein isolate. RC whey-MFGM100 contained more whey proteins than those of BM-MFGM100 and Lacprodan100. The presence of denatured whey proteins in MFGM materials before they were added to the $\mathrm{RC}$ was considered to play an important role in hindering the partial coalescence because the layer of denatured whey proteins is probably too dense for the crystals to protrude (Segall and Goff, 1999). Besides the effect of polar lipids, MFGM proteins and non-MFGM proteins (e.g. caseins and whey protein) can also provide stability. It has been reported by Vanderghem et al. (2010) that specific membrane proteins can provide the necessary emulsifying properties and contribute to emulsion stability. It was indeed pointed out by Kanno et al. (1991) and Oehlmann et al. (1994) that MFGM proteins play an important role in stabilizing the fat globules in the cream and reconstitute the milk fat in emulsions.

Besides, in emulsions, the crystallization behaviour and the emulsion stability can be affected to a large extent by the particle size distribution. The smaller the droplet, the higher the supercooling needed to induce crystallization (Walstra and Vanberesteyn, 1975; Lopez et al., 2002). The latter counts until the supercooling for homogeneous nucleation is reached. In the present study, the particle size average particle size of all RCs was not significantly different, and therefore, the effect of this factor was expected to be small. In NC, the droplet size is a consequence of a natural process, while the droplet size of RC depends on the energy-input during processing as well as on the availability of surface active materials (Ward et al., 2006). In RC, the PLs and proteins (caseins, whey proteins and MFGM-specific proteins) are present in the membrane and were found to have a strong effect on the whipping properties of RCs. The shear-induced partial coalescence rate was also affected by the fat crystallization behaviour and by the SFC of NC and RC (Figure 1 and Figure 2). The increased nucleation rate in the RCs was demonstrated by the increase in crystallization temperature observed upon cooling (see Table 3) implying a higher number of nucleation sites, and hence, more primary crystals within one droplet are shaped at the interface. After primary nucleation has occurred during cooling, crystallization will readily spread throughout the whole volume via secondary nucleation. The latter is favoured in milk fat because of its complex TAG-composition (Walstra, 1998). The difference in crystallization behaviour induced by different MFGM materials are considered to affect the $t_{c h}$ and the whipping properties of creams.

\section{Conclusion}

MFGM affected the physicochemical characteristics of RC. The present results demonstrated that the differences in the composition of the MFGM sources have a very important influence on the characteristics of the whipped RCs. When using BM-MFGM as an emulsifier, the crystallization started at a higher temperature and the crystal growth and the $\alpha-\beta$, 
polymorphic transition was accelerated compared to the NC. RC prepared with Whey-MFGM as the emulsifier (Whey-MFGM100) resulted in a long $t_{c h}$ due to the presence of a high amount of whey proteins, PLs, minerals and low amount of SFC. The use of $60 \%$ BMP in RC next to $40 \%$ of MFGM-enriched material was also found to have an impact on the physicochemical.

\section{Acknowledgments}

This work was financially supported by MOET (Ministry of Education and Training) (project number: 322) scholarship of Viet Nam. The authors would like to thank FrieslandCampina (Lummen, Belgium) for providing the buttermilk powder.

\section{References}

Britten, M., Giroux, H.J., Jean, Y. and Rodrigue, N. (1994). Composite blends from heat-denatured and undenatured whey protein: Emulsifying properties. International Dairy Journal, 4(1), 25-36. https:// doi.org/10.1016/0958-6946(94)90047-7

Contarini, G. and Povolo, M. (2013). Phospholipids in milk fat: composition, biological and technological significance, and analytical strategies. International Journal of Molecular Sciences, 14(2), 2808-2831. https://doi.org/10.3390/ijms14022808

Corredig, M., Roesch, R.R. and Dalgleish, D.G. (2003). Production of a novel ingredient from buttermilk. Journal of Dairy Science, 86(9), 2744-2750. https:// doi.org/10.3168/jds.S0022-0302(03)73870-3

Dickinson, E. (2010). Food emulsions and foams: stabilization by particles. Current Opinion in Colloid and Interface Science, 15(1-2), 40-49. https:// doi.org/10.1016/j.cocis.2009.11.001

Fredrick, E. (2011). Fat crystallization and partial coalescence in dairy creams: Role of monoacylglycerols. Ghent, Belgium: Ghent University, PhD. Dissertation.

Goff, H.D. (1997). Instability and partial coalescence in whippable dairy emulsions. Journal of Dairy Science, 80(10), 2620-2630. https://doi.org/10.3168/ jds.S0022-0302(97)76219-2

Ihara, K., Ochi, H., Saito, H. and Iwatsuki, K. (2011). Effects of buttermilk powders on emulsification properties and acid tolerance of cream. Journal of Food Science, 76(2), C265-271. https:// doi.org/10.1111/j.1750-3841.2010.02017.x

Kanno, C. (1989). Emulsifying properties of bovine milk fat globule membrane in milk fat emulsion: conditions for the reconstitution of milk fat globules. Journal of Food Science, 54(6), 15341539. 2621.1989.tb05153.x

Kanno, C., Shimomura, Y. and Takano, E. (1991). Physicochemical properties of milk fat emulsions stabilized with bovine milk fat globule membrane. Journal of Food Science, 56(5), 12191223. https://doi.org/10.1111/j.13652621.1991.tb04738.x

Le, T.T., Van Camp, J., Pascual, P.A.L., Meesen, G., Thienpont, N., Messens, K. and Dewettinck, K. (2011). Physical properties and microstructure of yoghurt enriched with milk fat globule membrane material. International Dairy Journal, 21(10), 798805. https://doi.org/10.1016/j.idairyj.2011.04.015

Lopez, C., Bourgaux, C., Lesieur, P., Bernadou, S., Keller, G. and Ollivon, M. (2002). Thermal and structural behavior of milk fat: Influence of cooling rate and droplet size on cream crystallization. Journal of Colloid and Interface Science, 254(1), 64-78. https://doi.org/10.1006/ jcis. 2002.8548

Melsen, J.P. (1987). The stability of recombined milk fat globules. Wageningen, Netherland: Agricultural University, PhD. Dissertation.

Miura, S., Mutoh, T., Shiinoki, Y. and Yoshioka, T. (2006). Emulsifying properties of phospholipids in the reconstitution of cream using butter oil. European Journal of Lipid Science and Technology, 108(11), 898-903. https:// doi.org/10.1002/ejlt.200600109

Oehlmann, S.M., Duncan, S.E. and Keenan, T.W. (1994). Butteroil Emulsification with Milk-Derived Membrane and Protein Fractions. Journal of Food Science, 59(1), 53-56. https://doi.org/10.1111/j.13652621.1994.tb06895.x

Phan, T.T.Q., Asaduzzaman, M., Le, T.T., Fredrick, E., Van der Meeren, P. and Dewettinck, K. (2013). Composition and emulsifying properties of a milk fat globule membrane enriched material. International Dairy Journal, 29(2), 99-106.

Rombaut, R., Dejonckheere, V. and Dewettinck, K. (2007). Filtration of milk fat globule membrane fragments from acid buttermilk cheese whey. Journal of Dairy Science, 90(4), 1662-1673. https://doi.org/10.1016/j.idairyj.2012.10.014

Scott, L.L., Duncan, S.E., Sumner, S.S. and Waterman, K.M. (2003). Physical properties of cream reformulated with fractionated milk fat and milkderived components. Journal of Dairy Science, 86 (11), 3395-3404. https://doi.org/10.3168/jds.S00220302(03)73943-5

Segall, K.I. and Goff, H.D. (1999). Influence of adsorbed milk protein type and surface concentration on the 
quiescent and shear stability of butteroil emulsions. International Dairy Journal, 9(10), 683-691. https:// doi.org/10.1016/S0958-6946(99)00143-0

van Lent, K., Le, C.T., Vanlerberghe, B. and Van der Meeren, P. (2008). Effect of formulation on the emulsion and whipping properties of recombined dairy cream. International Dairy Journal, 18(10-11), 1003-1010. https://doi.org/10.1016/ j.idairyj.2008.04.002

Vanapalli, S.A., Palanuwech, J. and Coupland, J.N. (2002). Stability of emulsions to dispersed phase crystallization: effect of oil type, dispersed phase volume fraction, and cooling rate. Colloids and Surfaces A: Physicochemical and Engineering Aspects, 204(1-3), 227-237. https://doi.org/10.1016/ S0927-7757(01)01135-9

Vanderghem, C., Bodson, P., Danthine, S., Paquot, M., Deroanne, C. and Blecker, C. (2010). Milk fat globule membrane and buttermilks: from composition to valorization. Biotechnologie, Agronomie, Société et Environment, 14(3), 485-500

Vanderghem, C., Danthine, S., Blecker, C. and Deroanne, C. (2007). Effect of proteose-peptone addition on some physico-chemical characteristics of recombined dairy creams. International Dairy Journal, 17(8), 889-895. https://doi.org/10.1016/ j.idairyj.2006.10.008

Vanhoutte, B., Foubert, I., Duplacie, F., Huyghebaert, A. and Dewettinck, K. (2002). Effect of phospholipids on isothermal crystallisation and fractionation of milk fat. European Journal of Lipid Science and Technology, 104(11), 738-744. https:// doi.org/10.1002/1438-9312(200211)

104:11<738::AID-EJLT738>3.0.CO;2-F

Walstra, P. (1998). Secondary nucleation in triglyceride crystallization. In Lindman, B. and Ninham, B.W. (Eds.) The Colloid Science of Lipid. Progress in Colloid and Polymer Science, Vol. 108. Germany: Steinkropff. https://doi.org/10.1007/BFb0117954

Walstra, P. and Van Beresteyn, E.C.H. (1975). Crystallization of milk fat in the emulsified state. Netherlands Milk and Dairy Journal, 29(1), 35 -65 .

Ward, R.E., German, J.B. and Corredig, M. (2006). Advanced Dairy Chemistry Volume 2: Lipids. In Fox, P.F. and McSweeney, P.L.H. (Eds.). Composition, applications, fractionation, technological and nutritional significance of milk fat globule membrane material, p. 213-244. Boston, USA: Springer. https://doi.org/10.1007/0-387-28813 $-9+6$
Wiking, L., Fredrick, E. and Dewettinck, K. (2009). Phospholipids delay crystallisation of milk fat. Milchwissenschaft, 64(4), 376-379. 